IV Congreso Internacional Estética y Política Poéticas del desacuerdo para una democracia plural 16 y 17 de octubre. Valencia

Doi: http://dx.doi.org/10.4995/CEP4.2019.10397

\title{
Aesthetic Upheaval due a Political Decision
}

\author{
Mustapha El Moussaoui
}

Universitat Politecnica de Valencia- musel@ doctor.upv.es

\begin{abstract}
Architecture since the beginning of time has been developed and shaped according to many aspects such as environmental factors, material availability, construction knowledge, religion, economy, and political decisions. In the current century, with the globalized building materials and increased awareness in architecture construction methods, architecture has hundreds of different ways to be constructed and developed. On the other hand, architecture is being formed and affected mainly due to economic factors, and political decisions. Bekaa Valley, a region in Lebanon can tremendously show this contemporary form of a changed aesthetic due to a political decision. The former is a region famous for its agricultural lands formed by million years of sediment clustering from rich Lebanese mountains bounding the area from the East and the West. The specific eastern area of Beka'a valley studied - Nabisheith to Douris-is full of farming lands, used by locals and nomads to grow a variety of vgetables, fruits, and wheat. A political decision lately developed by the minister of interior, to build houses by underdeveloped permits, changed the typology of a landscape created more than 2500 years ago. The architectural typology also changed to form new kind of architecture, which is indifferent to the local knowledge of construction learned and developed by locals. Local knowledge developed and adapted to endure harshness of weather by local materials replaced by globalized materials and abrupt political decisions. Such formation didn't only affect the aesthetics of landscapes picturesque sceneries and dwelling spaces but also raises an awareness of changing a cultural bond once famous in this particular region.
\end{abstract}

Keywords: Aesthetics, Politics, Dwelling, Landscape, Architecture

\section{Resumen}

Desde el principio de los tiempos, la arquitectura se ha desarrollado y transformado dependiendo de muchos aspectos tales como los factores ambientales, la disponibilidad de materiales, el conocimiento de la construcción, religión, economía y decisiones políticas. En la actualidad, con la globalización de los materiales de construcción y el aumento de la conciencia sobre los métodos de construcción arquitectónica, la arquitectura tiene cientos de formas diferentes de desarrollarse. Por otro lado, la arquitectura se está conformando respondiendo principalmente a factores económicos y decisiones políticas. Bekaa Valley, una región del Líbano, es un caso que evidencia esta evolución contemporánea de una estética transformada por una decisión política. Esta zona es una región famosa por sus tierras agrícolas formadas por millones de años de sedimentos que se agrupan en las ricas montañas libanesas que limitan el área desde el este y el oeste. La zona oriental específica del valle de Beka'a estudiada -de Nabisheith a Douris- está llena de tierras de cultivo, utilizadas por la población local y los nómadas para cultivar una variedad de hortalizas, frutas y trigo. Una decisión política tomada recientemente por el Ministro del Interior, de construir casas con permisos mínimos, cambió la tipología de un paisaje creado hace más de 2500 años. La tipología arquitectónica también cambió para conformar un nuevo tipo de arquitectura, indiferente al conocimiento local de la construcción. Este conocimiento local desarrollado y adaptado para soportar la dureza del clima por materiales locales se ve reemplazado por el uso de materiales globalizados y decisiones políticas abruptas. Estas construcciones no sólo afectan a la estética de los paisajes, tanto los paisajes pintorescos como los espacios habitables, sino también a la de los 
edificios de viviendas y desencadena la alarma respecto a la transformación de una tradición cultural por la que fue famosa esta región en particular.

Palabras clave: Estética, Política, Vivienda, Paisaje, Arquitectura

\section{Introduction}

Architecture as it started with the cradle of civilization has been always a huge part of shaping our cities. The city's architecture typology reflects its politics, economy, citizen's education, environmental factors, and its believes. On the other hand, politics has also started with the establishment of the first civilization, subsequently wanting to control the civilizans, homosapiens created the underlying linguistics and established systems in order to manage their land and its resources. Therefore, definitely architecture has been shaped a lot due to political decisions, in which, architecture always reflected the idea of the ruling system, and their political agenda. Building materials and environmental factors stopped being the major factor to shape our built environment, as with globalization, the building material of a specific culture have been replaced by international modernized materials.

The area studied in the Bekaa valley ${ }^{1}$ - Nabisheith to Douris - has experienced a major typological change in a relatively small time frame due to two major influences; New material use, and a political decision. As with the former - which we will not expand into - it only experienced new materials usage such as concrete and steel until the late 1960's. Moreover, even basic electrical connection was also established in the late 1960's. Therefore, inhabitants replaced timber, and Stone structures with concrete and steel materials. On the other hand, the political decisions (which we will discuss) is what caused the drastic change of its landscape and building typology.

Moreover, the damage didn't only disrupt the building typology, but also the dwelling experience and the psychological inhabiting experience of its dwellers, nonetheless I won't stress on the dwellers' experience, and their wellbeing, as it requires an expanded phenomenological study on the residents and their habitual experience.

\section{History}

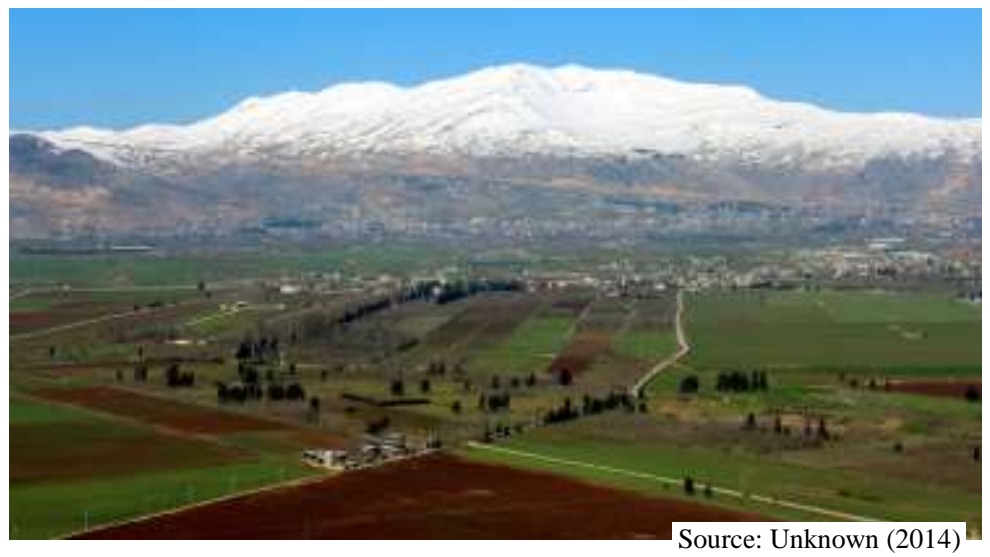

Fig. 1 Bekaa Valley

As mentioned earlier inhabitants witnessed technological advancements in the second half of the 20th century. While electricity reached this region after 1966, and according to the Mokhtar ${ }^{2}$ the first concrete building constructed was during the early 1970s. Before that, dwellers used to build their houses with natural stone and timber. They used to form their spaces according to the family need and their financial ability. Their dwelling spaces was built using local materials to sustain their living habits during the harsh winters and hot summers. Dwellers formed their own interior spaces to

\footnotetext{
1 Bekaa valley is considered to be Lebanon's most important farming region, allocating 42\% of all Lebanese arable land (MOA and FOA, 2000). The area served since the Roman empire as the grain source for the roman provinces in the Levant. Sandwished between two mountains that go up to $3000 \mathrm{~m}$; Mount Hermout from the east and Korne sawda from the west, the sedements from both mountains inrich its soil for farming (Lateef, 2007).

${ }^{2}$ Mokhtar is the head of a village, they are usually selected by some consensual or participatory method, often involving an election.
} 
accommodate several functions: food storage, living room, animal stables, animal food storage, bathrooms, and farming equipments.

Furthermore, dwellers didn't construct under any formal law, and without any engineering support. They built according to the local know-how material and familiarity, hence, what they learned from their parents, neighbors, and local masons. It wasn't until the 6th of March of 1951 the OEA (Order of Engineers and Architects) formed in Lebanon under the law 940, as before that a group of engineers created (Lebanese Organization for Civil Engineers and Architects) in $1934^{3}$.

Although it was formed in the 1950s, but locals relentlessly built without official documents for several reasons; law wasn't enforced on the rural areas as the country only lately gained its Independence (1947), the country always had a centralized authority, as reimbursing its attention only to the capital and other major cities in Lebanon, 26 years after forming the OEA, the Lebanese civil war ${ }^{4}$ started, and it remained until 1991 with the Taif agreement ${ }^{5}$. Moreover, in 1982 Israeli troops invaded Lebanon reaching Beirut. The state itself was in full chaos until earning its full Independence on the 25th of May 2000.

All the accommodated history pushed towards chaotic and illegal buildings constructed over time. Although the country was experiencing several devastating problems, but it didn't lead to the biggest aesthetic upheaval yet due

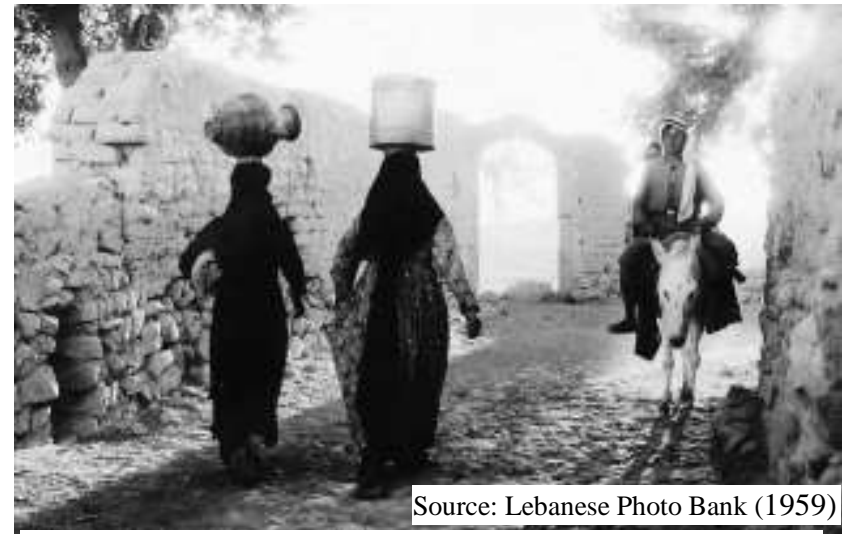

Fig. 2 Daily Village Life

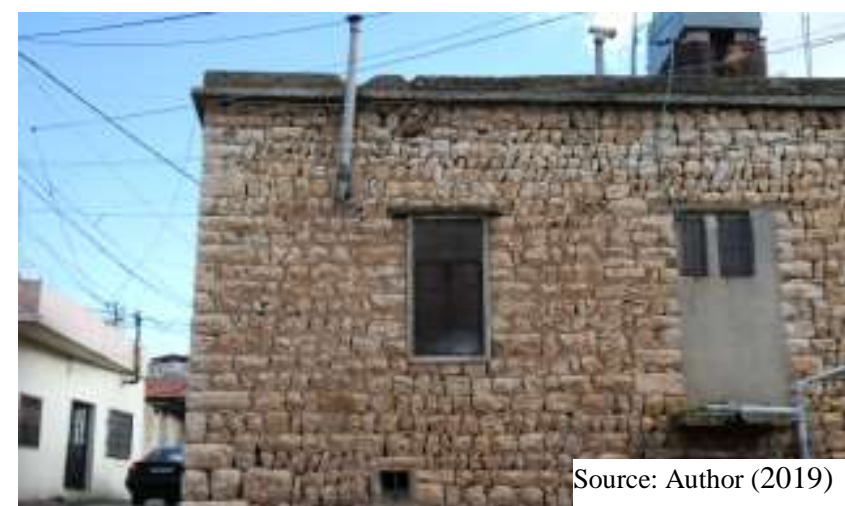

Fig. 2 Typical local dwelling, built on two phases 1920's and 1950's.

to several other reasons; residents lived deprived lives and couldn't afford building new houses, and citizens who immigrated during the war didn't invest back in their country.

After the year 2000, immigrated citizens started erecting their homes, but now legally under the Order of Engineers and Architect and according to the municipal of work laws.

\section{Political decision}

After the minister formation of 15 Feb 2014 under ex-prime minister Mr Tamam Salam, Mr. Nohad El- Mashnook was appointed to be the ministry of interior. Late on the same year, he approved a generalization (not an official law) for

\footnotetext{
3 OEA, “Historical Overview", https://oea.org.lb/Arabic/Sub.aspx?pageid=70 (Accessed August 15,2019)

${ }^{4}$ It was a multifaceted civil war in Lebanon, lasting from 1975 to 1990 and resulting in an estimated 120,000 fatalities

${ }^{5}$ Taif Agreement was an agreement reached to provide "the basis for the ending of the civil war and the return to political normalcy in Lebanon". Negotiated in Ta'if, Saudi Arabia, it was designed to end the decades-long Lebanese Civil War, reassert Lebanese authority in Southern Lebanon (then occupied by Israel), though the agreement set a time frame for Syrian withdrawal and stipulated that the Syrians withdraw in two years. It was signed on 22 October 1989 and ratified by the Lebanese parliament on 5 November 1989
} 
municipalities to give legislations for landlords in the rural areas to build without an official legislation from "OEA and the Municipal of Public Works $\&$ Transportation" constructions under $150 \mathrm{~m} 2$ under the generalization No. 613 on the 2014/5/5 (Fig 4) ${ }^{6}$.

The decision made was justified in the paper following by the minister; limiting the chaotic construction, preventing urbanization, and allowing citizens living in areas without municipalities to build their dwelling spaces.

The rule briefly announces that the construction must be strictly 1 floor no more than 3 meters and under $150 \mathrm{~m} 2$ including terraces and verandas. Moreover, the decision states ". the building must comply with the construction law, specially the setbacks, and that according to the procedures and terms specified in the circular board.." (Fig 4).

Additionaly, the landlord can build two floors in this area and can add a basement if the level of the property is below the level of the road adjacent to the building facade. Those who have benefited from a similar generalization in the past can build an additional floor above their home. On the other hand, the task of controlling the application of these permits was transferred to the

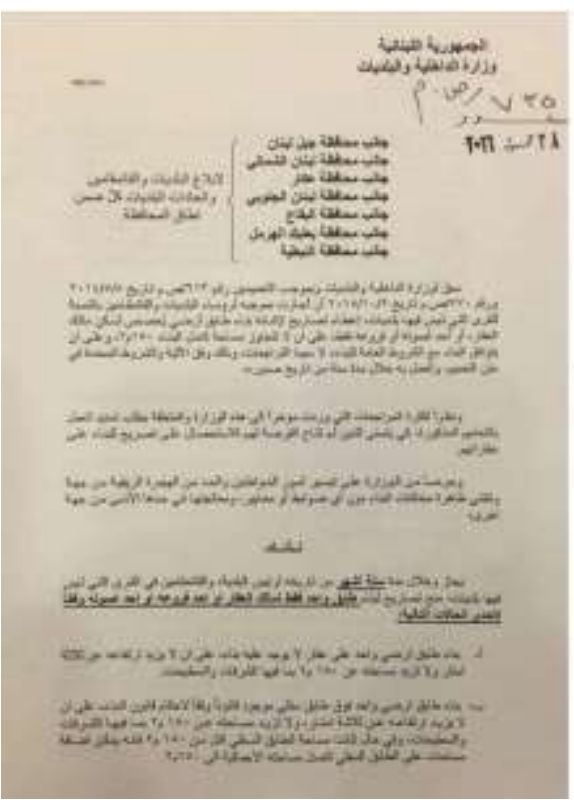

Source: Munc. of Nabisheith, (2016) security forces.

\section{Implication}

Although in the Genarlization No. 613/sa.m, states clearly that all licensed structures must comply with the construction law, and its setbacks. The implication of the building construction under the "Municipal Licenses" has shifted otherwise.

Any land lord, presenting a $150 \mathrm{~m} 2$ plan - to the local municipality - signed by any sort of engineer (architect, civil, electrical, mechanical, topographer..), paying a fee of $300 \$$, will be granted the license. The plan presented to the municipality is usually a paper without context, without its fixation on site, sections, structural, elevations, mechanical, or electrical plan.

How things work usually in the rural area, is a local foreman who has some construction knowledge, draws the plan which it will be a max of $4 \times 4 \times 4 \mathrm{~m}$ concrete span between columns $(60 \times 30 \mathrm{~cm})$ and $9 \mathrm{~m}$ depth (Fig 5), will accomulate a total of 150 square meters. Later on, the landlord, will find any of his relative engineers, to sign on the $2 \mathrm{~d}$ plan for the municipal approval ${ }^{7}$. How citizens complied with the rule is the following; usually most of the people building these kind of structure already have homes. But, what the license granted the land lords of the studied area is structures on the main road connecting the village to the highway of (Beirut - Hermel) -a vast open space of

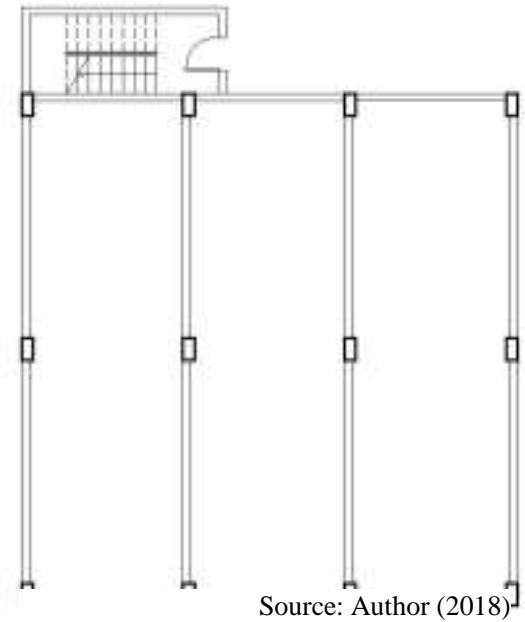

Fig. 4 Typical Modular used for construction

\footnotetext{
${ }^{6}$ The generalization is valid for 6 month, and has been renewed for 4 times under Al Mashnook reign, in 2014 (No. 613 ), 2015 (No. 770 ), 2016 (No. 735 ) and 2017 (No.352).

${ }^{7}$ The engineer (Architect, civil, electrical, etc..) who signs the plan for the landlord, is not double checked by the municipality if he truly is associated with the sendicate of engineers and architects, or not. He might be not registered in any form of engineering, as the municipality doesnt have any access to the (OEA or Municipal) files for names of registered engineers.
} 


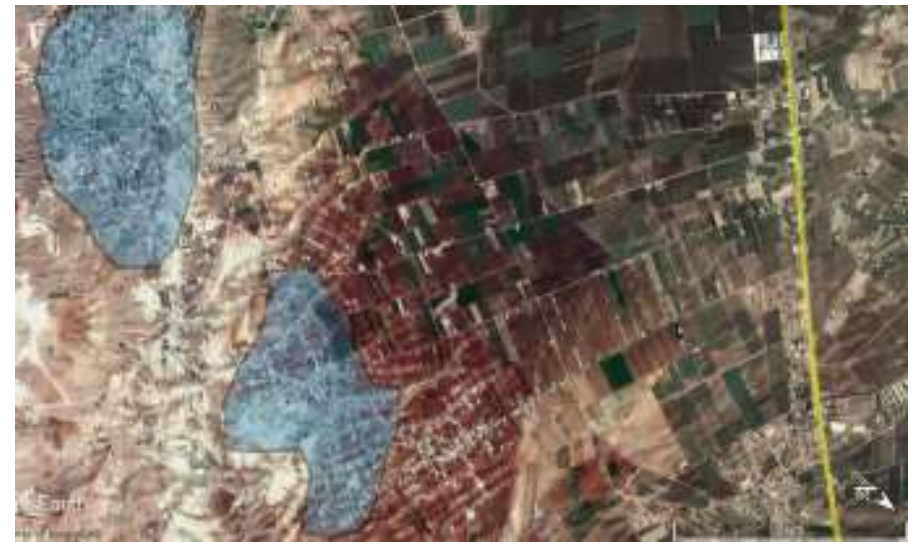

Source: Google Earth (2019)

Fig. 5 Part of the Bekaa Valley, Main road (Yellow) Villages overlooking the valley (Blue).

Corbusier's Do-mino module (Fig 7) created and developed in 1914. According to Le Corbusier the do-mino prototype became suitable for mass-production housing during the post-war reconstruction. Although the do-mino module was severly criticized by architects and theorists, it took exactly 100 years from requesting the patent (with Emil Mörsch) in 1914 (Brooks, 1997) to its implication in its Lebanese form in the Bekaa

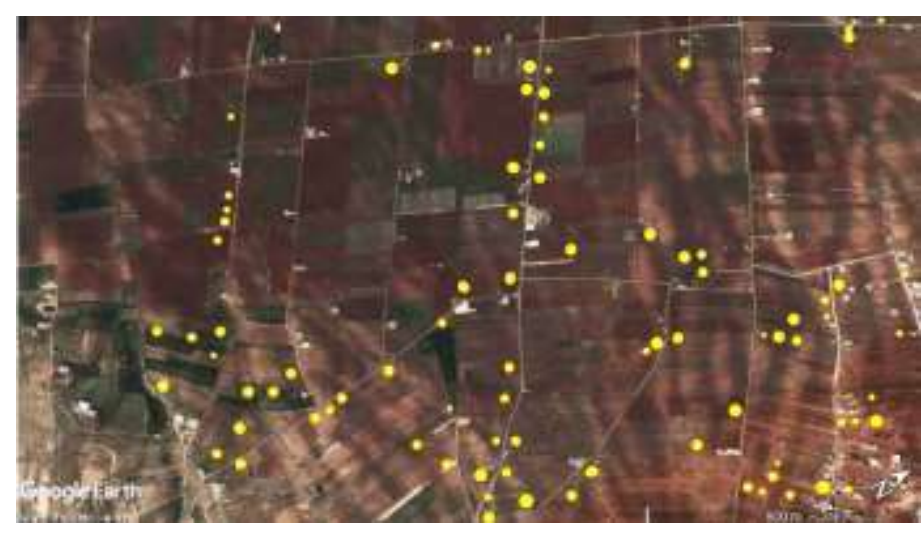

Source: Google Earth (2014)

Fig. 8 An image from google earth captured in 2014. The yellow dots are the new constructions that formed in the specific area.

show the number of constructed houses from 2014-2018. Nonetheless, we can not assume that all the constructions are of the "Lebanese Modular", as definetly there are some houses that are constructed with a legal license. The number of new houses constructed from 2014-2018 in (Fig.8) exceeds 85 new constructions. Fig.9 is an image of a typical "Lebanese Modular" in the Bekaa valley. farming lands (fig 6) - Structures consisting of 3 shops $(4 \times 4 \times 4)$ by a depth of $8-9 \mathrm{~m}$. Soo they would be rented for profit. The "local modular" (Fig 5) spread like fire between citizens causing a vast chaos of the farming land picturesque landscape. Moreover, the "Local Modular" evolved, as the land-lord, eventually will inquire another license, so he would build another floor above the first license, and later on he will add a pitched roof. The $1^{\text {st }}$ floor will contain offices and the ground floor will have local shops. A total of 450 meters squared concrete structures sprout in the midst of farming lands.

The "Lebanese Modular" reminds us Le

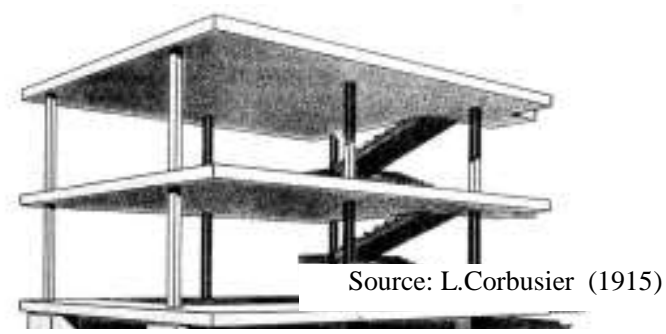

Fig. 7 Le Corbusier's Do-mino Module

valley, after 2014. Moreover, through all the different ideological forces behind the contribution to both modules - Do-mino, and the Lebanese Module- Mr. Nohad al Mashnook's decision and Le Corbusier idea, both, had an intitial progressive idea for the future of a city, but we will detain the after-math of its implication in the near future.

In Fig. 8 we see a satellite image demonstrating the new constructed buildings since 2014. The image

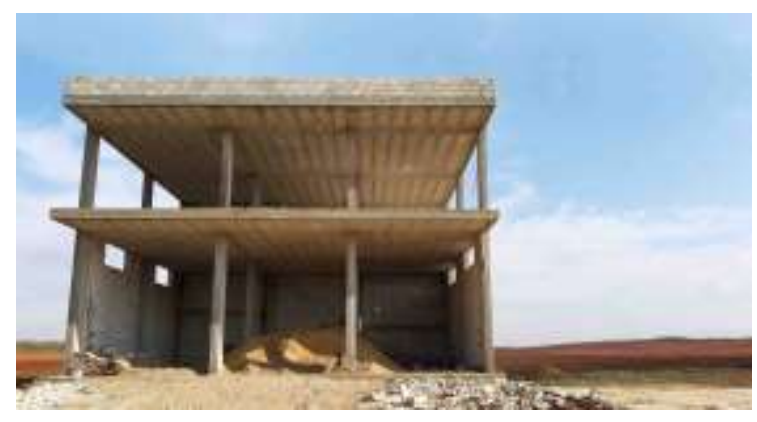

Source: Author (2019)

Fig. 9 Lebanese modular in the Bekaa Valley

\section{5- Conclusion}


Architecture since the begnning of civilization has been shaped by several factors, one of the most important factors is its political system. Moreover, whatever shapes our architectural aesthetics is a show case of the existing -local and international- zeitgeist.

In Lebanon, a political decision issued on the $5^{\text {th }}$ of May 2014, by the municipal of interior Mr Nohad al Mashnooq created an irreversible damage. The harm is already done, and is residing for the next 100 years at least, destroying a picturesque landscape been agrigated and used as crop growing farms for more than 2000 years. The concrete modular sprouting in

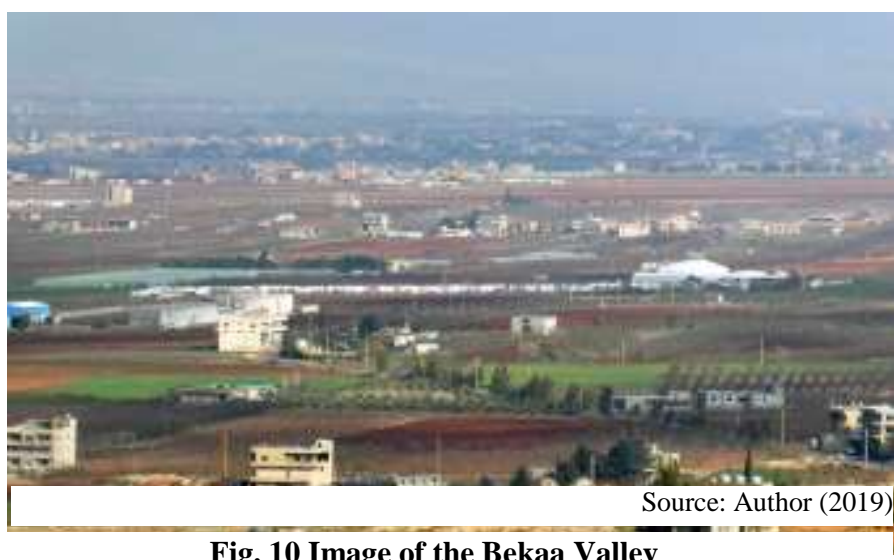

Fig. 10 Image of the Bekaa Valley the middle of farming lands maybe an alarming sign for a less farming communities in the future and more of business greed structures. On the other hand, Mr. Jad Tabet - President of the OEA- tried several times to challenge the "Generalization", but with no success.

In the near future, our children to come, will doom us for leaving them a legacy of concrete blocks, and less farming lands, landscapes that they will be in a devastating need to aggregate with our current world environmental alarming deforstration. The political dicision didn't impact only the aesthetics of a landscape and architecture, but also, it will definetly have a phsycological outcome on its.

Mr. Nohad al Mashnooq may have had a progressive idea to service citizens of the rural areas on building their dwelling spaces, and slowing urbanization, but such decision, definitely, needed a consultation of professionals and experts in the fields of urban planning, forestation, landscaper, architects, anthropologists, etc... On the other hand, the aesthetic upheaval isn't a pure responsibility of Mr. Nohad al Mashnook, rather, several other parties contributed to the upheaval. Finally, The generalization - which was in continuos renewal every 6 month - came to an end with the 2018 elections, with the election of a new Minister of Interior, Mrs. Al Hassan.

\section{6- References}

Ayoub, L. (2017). Al Mashnook Behelat Mosharea: Ebno Ma Tab Lakom.. Beirut. Mofakera Qanooneya. < http://legalagenda.com/article.php?id=4031> (Accessed: August 18 2019).

BrooKs, H. A. (1997). Le Corbusier's Formative Years. Chicago and London: Univ. Chicago Press. (in French)

Corbusier, L., and Jeanneret, P. (1960). Oeuvre Complète 1910-1929. 7th ed. Zurich: Éditions Girsberger, 23. (in French)

Daily ViLlage LiFE (1959). Lebanese Photo Bank <https://lebanesephotobank.wordpress.com/2014/10/02> (Accessed: August 23 2019)

Krayem, H. (2009). "The Lebanese civil war and the Taif agreement". American University of Beirut. <http://ddc.aub.edu.lb/projects/pspa/conflict-resolution.html>, (Accessed: August 23 2019)

LATEEF, A.S. (2007) Geological history of the Bekaa Valley-Lebanon. In Second International Conference on the Geology of the Tethys; Cairo University: Cairo, Egypt, 2007; pp. 391-402.

MOA and FAO. (2000). "Résultats globaux du recensement agricole. Ministère de l'Agriculture, FAO, Projet 'Assistance au recensement agricole'. P.122.

UN Human Rights Council (2006). "Implementation of General Assemble Resolution 60/251 of 15 March 2006 Entiteled Human Rights Council" November 23 2006, p.18. 